\title{
Effects of dietary supplementation of red ginseng root powder on performance, immune system, caecal microbial population and some blood parameters in broilers
}

\author{
Yavuz YENER $^{1, a}$, Sakine YALÇIN ${ }^{2, b, \bowtie}$, İrfan ÇOLPAN $^{2, c}$ \\ ${ }^{1}$ Ministry of Agriculture and Forestry, Department of Internal Audit, Ankara; ${ }^{2}$ Ankara University, Faculty of Veterinary Medicine, \\ Department of Animal Nutrition and Nutritional Disease, Ankara, Turkey. \\ aORCID: 0000-0001-9993-7802; ' ${ }^{\mathrm{a} O R C I D: ~ 0000-0001-8640-2729 ; ~ ' ~}{ }^{\mathrm{ORCID}}$ : 0000-0001-5357-4479
}

Corresponding author: sayalcin@ankara.edu.tr

Received date: 08.04.2020 - Accepted date: 13.09.2020

\begin{abstract}
The aim of the research was to determine the effects of red ginseng root powder on performance, immune system, caecal microbial population and some blood parameters in broilers. A total of 224 daily Ross 308 male broiler chicks were divided into one control group and three experimental groups each containing 56 chicks. Red ginseng root powder was added to the diets of groups at the level of $0,75,150$ and $225 \mathrm{mg} / \mathrm{kg}$, respectively. The experimental period was 38 days. There were no differences in growth performance. Addition of $225 \mathrm{mg} / \mathrm{kg}$ of the red ginseng root powder increased the relative weight percentages of spleen and gizzard $(\mathrm{P}<0.05)$. Ginseng root powder supplementation didn't affect biochemical parameters and antibody titers in blood serum. The values of haemoglobin, leukocytes, red blood cell distribution width and mean corpuscular haemoglobin concentration in group fed diet supplemented with $225 \mathrm{mg} / \mathrm{kg}$ ginseng were increased significantly $(\mathrm{P}<0.001)$. The count of Lactobacillus spp. in the caecum $(\mathrm{P}<0.05)$ was increased with $75 \mathrm{mg} / \mathrm{kg}$ ginseng root powder addition. As a result, improvements were provided in immune organ weight and some hematological parameters with the addition of $225 \mathrm{mg} / \mathrm{kg}$ and in Lactobacillus spp. count in caecum with the addition of 75 $\mathrm{mg} / \mathrm{kg}$ red ginseng root powder to the diets in broilers. Further studies are required to evaluate the bioavailability of the active compounds of red ginseng root powder and to determine the effects of its various doses on performance, immunity, antioxidant potential and intestinal microflora under various stress conditions in poultry.
\end{abstract}

Keywords: Broiler, immunity, microbial population, performance, red ginseng root powder.

\section{Broyler rasyonlarına kırmızı ginseng kökü tozu ilavesinin performans, immun sistem, sekal mikrobiyel populasyon ve bazı kan parametreleri üzerine etkisi}

Özet: Bu araştırmanın amacı, broyler karma yemlerine kırmızı ginseng kökü tozu ilavesinin performans, immun sistem, sekal mikrobiyel popülasyon ve bazı kan parametreleri üzerine etkilerini belirlemektir. Toplam 224 adet günlük Ross 308 erkek broyler civciv her biri 56 civciv içeren bir kontrol ve üç deneme grubuna ayrılmıştır. Kırmızı ginseng kökü tozu grup yemlerine sırasıyla 0,75 , 150 ve $225 \mathrm{mg} / \mathrm{kg}$ düzeylerinde ilave edilmiştir. Deneme süresi 38 gündür. Gruplar arasında büyüme performansı bakımından farklılık gözlenmemiştir. Kırmızı ginseng kökü tozunun $225 \mathrm{mg} / \mathrm{kg}$ düzeyinde ilavesi dalak ve taşlığın relatif ağırlık yüzdesini artırmıştır $(\mathrm{P}<0,05)$. Ginseng kökü tozu ilavesi kan serumunda biyokimyasal parametreleri ve antikor titresini etkilememiştir. Yemine $225 \mathrm{mg} / \mathrm{kg}$ ginseng ilave edilen grubun kanında hemoglobin, lökosit, eritrosit dağılım genişliği ve ortalama eritrosit hemoglobin konsantrasyonu önemli derecede $(\mathrm{P}<0,001)$ artmıştır. Sekumda Lactobacillus spp. sayısı yeme $75 \mathrm{mg} / \mathrm{kg}$ ginseng kökü tozu ilavesi ile artmıştır $(\mathrm{P}<0,05)$. Sonuçta kırmızı ginseng kökü tozunun $225 \mathrm{mg} / \mathrm{kg}$ ilavesi broylerlerde immun organ ağırlığında ve bazı hematolojik parametrelerinde, $75 \mathrm{mg} / \mathrm{kg}$ ilavesinin ise sekumda Lactobacillus spp. sayısında iyileşme sağlamıştır. Kırmızı ginseng kökü tozu aktif bileşenlerinin biyoyararlanılabilirliğini incelemek ve farklı dozlarının çeşitli stres şartlarındaki kanatlılarda performans, immunite, antioksidan potansiyel ve bağırsak mikroflorasını belirlemek için yapılacak çalışmalara ihtiyaç duyulmaktadır.

Anahtar sözcükler: Broyler, immunite, kırmızı ginseng kök tozu, mikrobiyel popülasyon, performans.

\section{Introduction}

Ginseng (Panax ginseng C.A. Meyer) is a perennial plant that grows in shaded and humid areas throughout
Korea, Japan and China. It is widely used as medicinal herbs, food and flavoring agent in the world $(7,10)$. Red ginseng is one of the categories of ginseng depending on 
the manufacturing method (29). Ginseng has many biological activities such as antioxidant, antistress, antidiabetic, anticarcinogenic activities and immune modulator due to containing various bioactive compounds such as saponins, antioxidants, peptides, polysaccharides, alkaloids, lignans and polyacetylenes. Red ginseng has the most health benefits in all of the ginseng categories due to the high saponin content. Saponins have immune enhancer, anti-fatigue, antioxidant and hepato-protective physiological effects $(24,27)$. More than 30 different ginsenosides (saponins) having different pharmacological activities have been isolated and characterized (31).

Ginsan, a polysaccharide isolated from the root of Panax ginseng C.A. Meyer, has been shown to be a potent immunomodulator, producing several cytokines and stimulating lymphoid cells to proliferate $(25,30,36,39,40)$.

Lim et al. (31) suggested that fine ginseng root fractions could have antioxidant and antimicrobial effects. Yan et al. (43) concluded that the use of $0.1 \%$ wildginseng root meal in the diets could increase growth performance and weight of immune organs, while decrease abdominal fat and serum cholesterol. However, some researchers reported that dietary supplementation with fermented red ginseng extract (3) and Korean ginseng root extract (44) did not influence performance and egg quality in laying hens. To the best of our knowledge, limited study has been published on the effects of red ginseng root powder in broilers. Therefore, this experiment was aimed to determine the effects of red ginseng root powder supplementation on performance, immunity, caecal microflora and some blood parameters in broilers.

\section{Materials and Methods}

All study were approved by the Animal Ethics Committee of the Ankara University (2015-4-71).

Animals and diets: A total of 224 daily Ross 308 male broiler chicks were divided to four groups and each group had 7 replicates of 8 chicks each. Each replicates were placed in separate floor pen having $80 \mathrm{~cm}$ width $\mathrm{x} 90$ $\mathrm{cm}$ length $x 80 \mathrm{~cm}$ height. Zeolite (ZETA, 1-2 mm of particulate size-Gördes Zeolite Madencilik Sanayi Tic A.Ş.-İzmir) was used as a litter. There were two nipples and one hanging suspended feeder in each pen. Water and mash feed were ad libitum during 38 days. Lighting was permanently applied. Temperature of room was $32 \pm 2^{\circ} \mathrm{C}$ on the first week and then gradually reduced to $24-26^{\circ} \mathrm{C}$ and this temperature was maintained upto slaughtering. The ingredients and chemical composition of the basal diets were given in Table 1. The diets were formulated to

Table 1. The ingredients and chemical composition of the basal diets (as-fed basis).

\begin{tabular}{|c|c|c|}
\hline Ingredients (g/kg) & $\begin{array}{l}\text { Starter diet } \\
0-21 \text { days }\end{array}$ & $\begin{array}{l}\text { Grower diet } \\
22-38 \text { days }\end{array}$ \\
\hline Corn & 503.0 & 484.0 \\
\hline Soybean meal & 240.0 & 172.0 \\
\hline Full fat soya & 209.7 & 265.0 \\
\hline Sunflower seed oil & 12.0 & 40.0 \\
\hline Limestone & 9.0 & 9.0 \\
\hline Dicalcium phosphate & 24.0 & 20.0 \\
\hline Methionine & 3.7 & 2.5 \\
\hline Lysine & 2.0 & 1.5 \\
\hline Sodium bicarbonate & 1.0 & 1.0 \\
\hline Salt & 2.5 & 2.5 \\
\hline Vitamin premix $^{1}$ & 1.5 & 1.5 \\
\hline Mineral premix ${ }^{2}$ & 1.0 & 1.0 \\
\hline Salinomycine & 0.6 & - \\
\hline \multicolumn{3}{|l|}{ Chemical composition (Analyzed) } \\
\hline Metabolizable energy ${ }^{3}(\mathrm{kcal} / \mathrm{kg})$ & 3010 & 3210 \\
\hline Crude protein $(\mathrm{g} / \mathrm{kg})$ & 220.2 & 211.0 \\
\hline Ether extract $(\mathrm{g} / \mathrm{kg})$ & 69.4 & 98.4 \\
\hline Crude fibre $(\mathrm{g} / \mathrm{kg})$ & 48.2 & 41.0 \\
\hline Crude ash (g/kg) & 56.2 & 53.4 \\
\hline Calcium $(\mathrm{g} / \mathrm{kg})$ & 12.0 & 10.8 \\
\hline Total phosphorus (g/kg) & 9.1 & 8.2 \\
\hline
\end{tabular}

1: Provides $1.5 \mathrm{~kg}$ of premix: $11000000 \mathrm{IU}$ vitamin A, 3500000 vitamin $\mathrm{D}_{3}, 100 \mathrm{~g}$ vitamin E, $3 \mathrm{~g}$ vitamin K3, $3 \mathrm{~g}$ vitamin $\mathrm{B}_{1}, 6 \mathrm{~g}$ vitamin $\mathrm{B}_{2}$, $35 \mathrm{~g}$ niacin, $15 \mathrm{~g}$ calcium D pantothenate, $1 \mathrm{~g}$ vitamin $\mathrm{B}_{6}, 20 \mathrm{mg}$ vitamin $\mathrm{B}_{12}, 1500 \mathrm{mg}$ folic acid, $200 \mathrm{mg}$ D-biotin.

2: Provides 1 kg of premix: 120 g Mn, 50 g Fe, 100 g Zn, 30 g Cu, 2 g I, 200 mg Co, 300 mg Se.

3: Metabolizable energy content of diets was calculated (5). 
meet or exceed the nutrient requirements of broilers based on the management guide of Ross 308. Basal diets were supplemented with 0 (control), 75, 150 and $225 \mathrm{mg} / \mathrm{kg}$ Panax red ginseng root powder (Daedong Korea Ginseng Co. Ltd). Control group diet consisted of only basal diet.

Traits measured: Nutrient composition of basal diet was analyzed (4) for crude protein (CP, Method 968.06), ether extract (EE, Method 920.39), crude fiber (CF, Method 932.09) and ash (Method 967.05). Calcium (11) and total phosphorus (1) were analyzed. Metabolizable energy levels of diets were estimated (5).

All of the birds were weighed individually at day 1 , $7,14,21,28,35$ and 38 to determine weight gain. Feed intake was determined at these weighing days and feed conversion ratio (FCR) was calculated as $\mathrm{kg}$ feed per $\mathrm{kg}$ weight gain. Livability and European Production Efficiency Factor (EPEF) values of groups were calculated according to the following formula (28): Livability, $\%=$ (Number of live bird at the end / Number of birds at the beginning $) \times 100$ and EPEF $=(($ Livability, \%) $\times$ (Body weight, $\mathrm{kg}) \times \mathrm{100}) /(($ Age, day) $\mathrm{x}$ (FCR, $\mathrm{kg}$ feed/kg gain)).

Newcastle disease vaccine (Live attenuated, Lasota strain, Phibro Animal Health Products Corp.) was made at the begining and $14^{\text {th }}$ day using the eyedrop method.

At the $28^{\text {th }}$ day one bird from each replicate (7/group) was randomly selected, weighed and slaughtered. Blood samples were also taken from the wing vein into plain and EDTA-coated tubes. Blood samples from two birds of each replicate (14/group) were also taken from the wing vein into plain and EDTA-coated tubes at the $38^{\text {th }}$ day of the experiment. Blood serum samples at the $28^{\text {th }}$ and $38^{\text {th }}$ day were used to make biochemical analyses and to determine the specific antibody titer against Newcastle Disease virus in vaccinated broilers using Hemagglutination Inhibition Test (2). Total protein, albumin, globulin, creatinine, urea, triglyceride, total cholesterol, LDL, ALT, AST and GGT levels were determined with an autoanalyzer (BT 3000, Biotechnica Instruments, Italy) using commercial kits of Randox RX series (Randox Laboratories Ltd., London, United Kingdom). Blood taken on EDTA-coated tubes on the 38th day was used to determine hematological parameters with automated hematology analyzer (Sysmex pocH100iV, Sysmex Corporation, Japan).

At the $38^{\text {th }}$ day two birds from each replicate (14/group) were randomly selected, weighed and slaughtered. Hot carcasses were weighed and carcass yields were calculated. Internal organs of bursa Fabricius, heart, kidney, liver, spleen, abdominal fat (only $38^{\text {th }}$ day) and gizzard of the slaughtered birds at $28^{\text {th }}$ and $38^{\text {th }}$ day were removed, weighed and relative weights of internal organs were calculated by dividing these weights to slaughtering weight.

Caecum samples from slaughtering birds at the 38th day were collected in sterile containers for the determination of the number of total aerobic bacteria (12), coliform (17) and Lactobacillus spp. (16).

Statistical analyses: SPSS programme (SPSS Inc., Chicago, IL, USA) was used for statistical analyses. Kolmogorov-Smirnov test was applied for the normality of data distribution. One-way ANOVA was used to detect the effects of ginseng supplementation on different parameters. Comparisons among means were done by Tukey test. Polynomial contrasts were used to determine the linear, quadratic and cubic effects of ginseng supplementation on different parameters. Statistical significance level was accepted as $\mathrm{P}<0.05$ (9).

\section{Results}

Effects of dietary ginseng supplementation on performance parameters were shown in Table 2. Different ginseng supplementation into broiler diets had no effect on body weight, body weight gain, feed intake, feed conversion ratio, livability and EPEF when compared to the control group. As shown in Table 3, no significant effects were observed in relative organ weight percentages on day 28 , however relative weight percentages of spleen and gizzard of group fed $225 \mathrm{mg} / \mathrm{kg}$ ginseng on day 38 were found to be significantly higher than those of control group $(\mathrm{P}<0.05)$. Blood serum biochemical parameters were not affected with dietary ginseng supplementation (Table 4). Blood levels of haemoglobin, red blood cell distribution width (RDW), leukocytes (white blood cell, WBC) and mean corpuscular haemoglobin concentration (MCHC) of group fed $225 \mathrm{mg} / \mathrm{kg}$ ginseng were found to be significantly higher $(\mathrm{P}<0.001)$ than those of control group (Table 5). As shown in Table 6, dietary ginseng supplementation at the level of $0,75,150$ and $225 \mathrm{mg} / \mathrm{kg}$ didn't affect hemagglutination inhibition levels in broilers. Dietary supplementation of red ginseng root powder at 75 $\mathrm{mg} / \mathrm{kg}$ increased the count of Lactobacillus spp significantly $(\mathrm{P}<0.05)$ as given in Table 7. 
Table 2. Effects of different levels of red ginseng root powder supplementation on performance of broilers.

\begin{tabular}{|c|c|c|c|c|c|c|c|c|c|}
\hline \multirow{2}{*}{$\begin{array}{l}\text { Performance } \\
\text { parameter }\end{array}$} & \multicolumn{4}{|c|}{ Red ginseng root powder, mg/kg } & \multirow{2}{*}{ SEM } & \multicolumn{4}{|c|}{ P-value } \\
\hline & $\mathbf{0}$ & 75 & 150 & 225 & & Combined & Linear & Quadratic & Cubic \\
\hline \multicolumn{10}{|l|}{ Body weight, $g$} \\
\hline 0 day & 44.20 & 44.11 & 44.24 & 44.39 & 0.072 & 0.620 & 0.313 & 0.421 & 0.785 \\
\hline 38 day & 2534.10 & 2515.17 & 2578.36 & 2582.24 & 18.359 & 0.509 & 0.223 & 0.762 & 0.403 \\
\hline \multicolumn{10}{|c|}{ Body weight gain, $g$} \\
\hline $0-21$ day & 773.47 & 732.06 & 777.17 & 755.57 & 9.784 & 0.358 & 0.922 & 0.615 & 0.091 \\
\hline 21-38 day & 1716.42 & 1738.99 & 1756.95 & 1782.28 & 15.599 & 0.517 & 0.140 & 0.966 & 0.933 \\
\hline 0-38 day & 2489.89 & 2471.05 & 2534.13 & 2537.85 & 18.367 & 0.513 & 0.225 & 0.764 & 0.404 \\
\hline \multicolumn{10}{|l|}{ Feed intake, $g$} \\
\hline 0-21 day & 1133.10 & 1088.25 & 1110.78 & 1089.60 & 7.972 & 0.150 & 0.125 & 0.443 & 0.115 \\
\hline 21-38 day & 3008.41 & 2970.37 & 3021.01 & 3067.23 & 18.925 & 0.357 & 0.189 & 0.273 & 0.585 \\
\hline 0-38 day & 4141.51 & 4058.62 & 4131.79 & 4156.83 & 19.589 & 0.305 & 0.497 & 0.175 & 0.248 \\
\hline \multicolumn{10}{|c|}{ Feed conversion ratio, $\mathrm{kg}$ feed/kg weight gain } \\
\hline 0-21 day & 1.466 & 1.490 & 1.435 & 1.447 & 0.014 & 0.561 & 0.389 & 0.858 & 0.266 \\
\hline 21-38 day & 1.754 & 1.709 & 1.721 & 1.725 & 0.011 & 0.550 & 0.464 & 0.291 & 0.514 \\
\hline 0-38 day & 1.664 & 1.643 & 1.632 & 1.641 & 0.009 & 0.683 & 0.353 & 0.446 & 0.911 \\
\hline Livability, \% & 97.96 & 95.92 & 97.96 & 97.96 & 1.053 & 0.886 & 0.838 & 0.648 & 0.540 \\
\hline EPEF & 392.82 & 387.26 & 407.89 & 407.77 & 7.128 & 0.676 & 0.328 & 0.855 & 0.481 \\
\hline
\end{tabular}

$\mathrm{n}=7$, No significant differences among groups.

Table 3. Effects of red ginseng root powder supplementation on relative organ weights and carcass yield.

\begin{tabular}{|c|c|c|c|c|c|c|c|c|c|}
\hline \multirow{2}{*}{ Item } & \multicolumn{4}{|c|}{ Red ginseng root powder, $\mathrm{mg} / \mathrm{kg}$} & \multirow{2}{*}{ SEM } & \multicolumn{4}{|c|}{ P-value } \\
\hline & $\mathbf{0}$ & 75 & 150 & 225 & & Combined & Linear & Quadratic & Cubic \\
\hline \multicolumn{10}{|c|}{ Relative organ weights on day $28, \%(n=7)$} \\
\hline Liver & 2.272 & 2.195 & 2.268 & 2.231 & 0.033 & 0.843 & 0.873 & 0.778 & 0.405 \\
\hline Heart & 0.607 & 0.623 & 0.649 & 0.637 & 0.009 & 0.426 & 0.172 & 0.458 & 0.564 \\
\hline Gizzard & 1.816 & 1.790 & 1.829 & 1.852 & 0.019 & 0.714 & 0.398 & 0.533 & 0.633 \\
\hline Bursa Fabricius & 0.232 & 0.228 & 0.210 & 0.253 & 0.010 & 0.521 & 0.612 & 0.257 & 0.410 \\
\hline Spleen & 0.089 & 0.087 & 0.106 & 0.080 & 0.005 & 0.327 & 0.824 & 0.260 & 0.147 \\
\hline $\begin{array}{l}\text { Carcass yield on day } 38, \\
\%(n=14)\end{array}$ & 70.46 & 70.43 & 70.73 & 70.19 & 0.150 & 0.667 & 0.706 & 0.403 & 0.399 \\
\hline \multicolumn{10}{|c|}{ Relative organ weights on day $38, \%(n=14)$} \\
\hline Liver & 1.959 & 1.949 & 1.935 & 1.962 & 0.023 & 0.978 & 0.979 & 0.699 & 0.831 \\
\hline Heart & 0.464 & 0.490 & 0.500 & 0.503 & 0.006 & 0.088 & 0.019 & 0.323 & 0.861 \\
\hline Gizzard & $1.340^{\mathrm{b}}$ & $1.417^{\mathrm{ab}}$ & $1.454^{\mathrm{ab}}$ & $1.484^{\mathrm{a}}$ & 0.017 & 0.016 & 0.002 & 0.472 & 0.808 \\
\hline Bursa Fabricius & 0.213 & 0.219 & 0.196 & 0.199 & 0.005 & 0.240 & 0.116 & 0.817 & 0.193 \\
\hline Spleen & $0.108^{b}$ & $0.122^{\mathrm{ab}}$ & $0.115^{\mathrm{ab}}$ & $0.127^{\mathrm{a}}$ & 0.002 & 0.019 & 0.013 & 0.810 & 0.045 \\
\hline Abdominal fat & 1.096 & 1.211 & 1.181 & 1.138 & 0.027 & 0.474 & 0.703 & 0.154 & 0.586 \\
\hline
\end{tabular}

a,b: Means within a row followed by the different superscripts differ significantly $(\mathrm{P}<0.05)$. 
Table 4. Effects of dietary red ginseng root powder supplementation on blood serum parameters of broilers.

\begin{tabular}{|c|c|c|c|c|c|c|c|c|c|}
\hline \multirow[t]{2}{*}{ Blood serum parameters } & \multicolumn{4}{|c|}{ Red ginseng root powder, mg/kg } & \multirow{2}{*}{ SEM } & \multicolumn{4}{|c|}{ P-value } \\
\hline & $\mathbf{0}$ & 75 & 150 & 225 & & Combined & Linear & Quadratic & Cubic \\
\hline \multicolumn{10}{|l|}{ On day $28(n=7)$} \\
\hline Total protein, g/dl & 2.571 & 2.671 & 2.700 & 2.671 & 0.058 & 0.885 & 0.551 & 0.602 & 0.979 \\
\hline Albumin, g/dl & 0.929 & 0.943 & 0.957 & 0.957 & 0.021 & 0.961 & 0.616 & 0.872 & 0.943 \\
\hline Globulin, g/dl & 1.600 & 1.729 & 1.800 & 1.814 & 0.053 & 0.477 & 0.144 & 0.594 & 1.000 \\
\hline Creatinine, mg/dl & 0.307 & 0.331 & 0.294 & 0.274 & 0.025 & 0.891 & 0.571 & 0.678 & 0.742 \\
\hline Urea, mg/dl & 5.000 & 5.429 & 5.429 & 5.000 & 0.188 & 0.751 & 1.000 & 0.282 & 1.000 \\
\hline Triglyceride, mg/dl & 63.43 & 60.71 & 53.86 & 70.29 & 3.310 & 0.384 & 0.646 & 0.160 & 0.362 \\
\hline Total cholesterol, mg/dl & 106.43 & 101.29 & 95.86 & 109.43 & 2.220 & 0.140 & 0.851 & 0.036 & 0.316 \\
\hline LDL mg/dl, & 22.89 & 23.37 & 22.80 & 20.17 & 1.166 & 0.785 & 0.428 & 0.526 & 0.927 \\
\hline AST, IU/l & 333.57 & 346.14 & 338.86 & 298.00 & 15.608 & 0.726 & 0.437 & 0.415 & 0.925 \\
\hline ALT, IU/l & 2.429 & 2.000 & 2.714 & 2.429 & 0.188 & 0.630 & 0.682 & 0.854 & 0.225 \\
\hline GGT, IU/l & 20.14 & 20.86 & 21.86 & 21.57 & 0.681 & 0.830 & 0.413 & 0.728 & 0.807 \\
\hline \multicolumn{10}{|l|}{ On day $38(n=14)$} \\
\hline Total protein, g/dl & 2.764 & 2.607 & 2.657 & 2.607 & 0.036 & 0.364 & 0.191 & 0.455 & 0.339 \\
\hline Albumin, g/dl & 0.957 & 0.900 & 0.921 & 0.864 & 0.022 & 0.533 & 0.209 & 1.000 & 0.441 \\
\hline Globulin, g/dl & 1.871 & 1.657 & 1.750 & 1.743 & 0.044 & 0.395 & 0.458 & 0.243 & 0.304 \\
\hline Creatinine, mg/dl & 0.266 & 0.299 & 0.212 & 0.229 & 0.017 & 0.257 & 0.185 & 0.813 & 0.135 \\
\hline Urea, mg/dl & 6.714 & 7.286 & 6.429 & 6.214 & 0.230 & 0.390 & 0.256 & 0.396 & 0.318 \\
\hline Triglyceride, mg/dl & 43.93 & 50.07 & 51.64 & 52.21 & 1.756 & 0.325 & 0.097 & 0.429 & 0.820 \\
\hline Total cholesterol, mg/dl & 95.79 & 97.79 & 93.71 & 95.86 & 0.942 & 0.517 & 0.651 & 0.970 & 0.153 \\
\hline $\mathrm{LDL}, \mathrm{mg} / \mathrm{dl}$ & 26.50 & 25.99 & 23.81 & 24.27 & 0.901 & 0.679 & 0.284 & 0.791 & 0.602 \\
\hline AST, IU/l & 390.21 & 366.64 & 403.57 & 328.57 & 13.288 & 0.206 & 0.212 & 0.330 & 0.147 \\
\hline ALT, IU/l & 5.500 & 4.429 & 4.214 & 4.071 & 0.548 & 0.799 & 0.372 & 0.679 & 0.876 \\
\hline GGT, IU/l & 24.43 & 24.50 & 24.14 & 21.43 & 0.617 & 0.237 & 0.092 & 0.258 & 0.725 \\
\hline
\end{tabular}

No significant differences among groups.

Table 5. Effects of dietary red ginseng root powder supplementation on some hematological parameters on day 38 in broilers.

\begin{tabular}{|c|c|c|c|c|c|c|c|c|c|}
\hline & \multicolumn{4}{|c|}{ Red ginseng root powder, $\mathrm{mg} / \mathrm{kg}$} & \multirow{2}{*}{ SEM } & \multicolumn{4}{|c|}{ P-value } \\
\hline & $\mathbf{0}$ & 75 & 150 & 225 & & Combined & Linear & Quadratic & Cubic \\
\hline $\mathrm{RBC}, 10^{6} / \mu \mathrm{l}$ & 3.236 & 3.297 & 3.291 & 3.420 & 0.084 & 0.893 & 0.481 & 0.846 & 0.795 \\
\hline $\mathrm{WBC}, 10^{3} / \mu \mathrm{l}$ & $162.05^{\mathrm{b}}$ & $163.25^{\mathrm{b}}$ & $189.74^{\mathrm{a}}$ & $199.42^{\mathrm{a}}$ & 3.833 & $<0.001$ & $<0.001$ & 0.514 & 0.150 \\
\hline Hematocrit, \% & 30.54 & 31.21 & 32.62 & 29.03 & 0.562 & 0.150 & 0.526 & 0.058 & 0.246 \\
\hline Haemoglobin, g/dl & $7.169^{\mathrm{b}}$ & $7.386^{\mathrm{b}}$ & $7.696^{\mathrm{b}}$ & $8.855^{\mathrm{a}}$ & 0.152 & $<0.001$ & $<0.001$ & 0.071 & 0.512 \\
\hline Lymphocytes, \% & 56.82 & 55.55 & 59.43 & 54.07 & 1.337 & 0.551 & 0.718 & 0.452 & 0.238 \\
\hline Neutrophils, \% & 35.38 & 37.49 & 35.36 & 40.21 & 0.763 & 0.074 & 0.065 & 0.355 & 0.093 \\
\hline MCHC, g/dl & $23.33^{\mathrm{b}}$ & $24.79^{b}$ & $24.58^{\mathrm{b}}$ & $33.38^{\mathrm{a}}$ & 0.798 & $<0.001$ & $<0.001$ & 0.004 & 0.053 \\
\hline PDW, \% & 15.83 & 15.39 & 15.56 & 16.57 & 0.194 & 0.143 & 0.167 & 0.06 & 0.886 \\
\hline RDW, \% & $10.34^{\mathrm{c}}$ & $11.36^{\mathrm{bc}}$ & $12.31^{\mathrm{b}}$ & $15.51^{\mathrm{a}}$ & 0.348 & $<0.001$ & $<0.001$ & 0.026 & 0.280 \\
\hline
\end{tabular}

$\mathrm{n}=14,{ }^{\text {a,b,c: }}$ Means within a row followed by the different superscripts differ significantly $(\mathrm{P}<0.05)$.

RBC: Erythrocytes, Red Blood Cells, WBC: Leukocytes, White Blood Cells, MCHC: Mean Corpuscular Haemoglobin

Concentration, RDW: Red Blood Cell Distribution Width, PDW: Platelet Distribution Width 
Table 6. Effects of dietary red ginseng root powder supplementation on hemagglutination inhibition levels (ND antibody level) on day 28 and 38 in broilers.

\begin{tabular}{|c|c|c|c|c|c|c|c|c|c|}
\hline \multirow[t]{2}{*}{ Day } & \multicolumn{4}{|c|}{ Red ginseng root powder, mg/kg } & \multirow{2}{*}{ SEM } & \multicolumn{4}{|c|}{ P-value } \\
\hline & $\mathbf{0}$ & 75 & 150 & 225 & & Combined & Linear & Quadratic & Cubic \\
\hline $28(n=7)$ & 4.29 & 4.71 & 4.71 & 4.43 & 0.174 & 0.789 & 0.793 & 0.334 & 0.930 \\
\hline $38(n=14)$ & 2.64 & 2.79 & 3.00 & 2.71 & 0.116 & 0.733 & 0.686 & 0.367 & 0.590 \\
\hline
\end{tabular}

No significant differences among groups.

Table 7. Effects of dietary red ginseng root powder supplementation on caecum microflora $(\log 10 \mathrm{cfu} / \mathrm{g})$ on day 38 in broilers.

\begin{tabular}{|c|c|c|c|c|c|c|c|c|c|}
\hline \multirow[t]{2}{*}{ Microorganism } & \multicolumn{4}{|c|}{ Red ginseng root powder, $\mathrm{mg} / \mathrm{kg}$} & \multirow{2}{*}{ SEM } & \multicolumn{4}{|c|}{ P-value } \\
\hline & $\mathbf{0}$ & 75 & 150 & 225 & & Combined & Linear & Quadratic & Cubic \\
\hline Coliform & 7.19 & 6.86 & 7.08 & 7.04 & 0.139 & 0.872 & 0.850 & 0.607 & 0.530 \\
\hline Lactobacillus spp. & $6.49^{\mathrm{b}}$ & $7.14^{\mathrm{a}}$ & $6.75^{\mathrm{ab}}$ & $6.68^{\mathrm{ab}}$ & 0.072 & 0.010 & 0.768 & 0.010 & 0.026 \\
\hline Total aerobic bacteria & 7.80 & 7.62 & 7.79 & 7.70 & 0.063 & 0.738 & 0.818 & 0.750 & 0.297 \\
\hline
\end{tabular}

$\mathrm{n}=14,{ }^{\mathrm{a}, \mathrm{b}}$ : Means within a row followed by the different superscripts differ significantly $(\mathrm{P}<0.05)$.

\section{Discussion and Conclusion}

Dietary red ginseng root powder supplementation at the level of 75,150 and $225 \mathrm{mg} / \mathrm{kg}$ did not affect body weight, body weight gain, feed intake and feed conversion ratio during the 38 day of the experiment. Similar to the present results, supplementation of 0.5 and $1 \%$ Sibirya ginseng leaf (37), 5\% panax ginseng leaf (23), 1, 2 and 4 $\mathrm{g} / \mathrm{kg}$ ginseng plant extract (3) did not affect body weight and body weight gain. Özcan (34) reported that body weight and body weight gain in Japanese quails were not affected with the dietary supplementation of 5 and 10 $\mathrm{mg} / \mathrm{kg}$ panax ginseng root extract. According to the study of Yan et al. (43), body weight gain during weeks 3 to 5 and overall 5 weeks were improved with the dietary treatment of wild-ginseng adventitious root meal at $0.1 \%$, but did not differ at the level of 0.2 and $0.3 \%$. Muwalla and Abuirmeileh (32) reported that dietary supplementation of $0.25 \%$ Panax ginseng powder increased body weight gain.

Feed consumption was decreased with 5\% Panax ginseng leaves (23) and not affected with the dietary usage of 0.5 and $1 \%$ Sibirya ginseng leaves (37) and 1, 2 and 4 $\mathrm{g} / \mathrm{kg}$ ginseng plant extract (3). Similarly feed conversion ratio was not affected from the usage of 5\% panax ginseng leaves (23), 0.2 and $0.3 \%$ wild-ginseng root meal (43), 1 , 2 and $4 \mathrm{~g} / \mathrm{kg}$ ginseng plant extract (3) and $2 \%$ fermented ginseng marc (8). However $1 \%$ Sibirya ginseng negatively affected feed conversion (37).

Chung and Choi (8) reported that no significant differences between the different treatments (basal diet, $2 \%$ red ginseng marc, $1 \%$ fermented red ginseng marc with red koji and $2 \%$ liquid red ginseng) were found for final body weight, feed intake and feed conversion. Chung and Choi (8) also concluded that weight gain and mortality was most enhanced in the groups fed diets supplemented with $1 \%$ fermented red ginseng powder combined with red koji.

The performance of broiler was also evaluated in terms of EPEF which includes body weight and livability. No significant effects of dietary red ginseng root powder supplementation were observed in livability and EPEF in the present experiment. Similar result was obtained in laying hens (44).

Dietary ginseng supplementation didn't affect the relative weight percentages of liver, heart, bursa Fabricius, gizzard and spleen on day 28 (Table 3). Carcass yield and the relative weight percentages of liver, heart, bursa Fabricius and abdominal fat was not affected by ginseng plant supplementation at the end of this experiment (Table 3). However the relative weight percentages of spleen and gizzard on day 38 were increased $(\mathrm{P}<0.05)$. Linear increases $(\mathrm{P}<0.05)$ were seen in the relative weight percentages of spleen and gizzard with an increase in the doses of red ginseng root powder. Measurement of immune organ weight is a method to determine the immune status of birds (15). For optimum immunoglobulin synthesis, the development of these organs are very important (13). In the present experiment relative spleen weight also increased with $225 \mathrm{mg} / \mathrm{kg}$ ginseng root extract supplementation and it was also observed that linear effects were seen with the dose of ginseng root extract. In the study of Yan et al. (43), 0.1, 0.2 and $0.3 \%$ wild-ginseng root meal (WGM) supplementation did not affect the relative weight of liver 
and gizzard however relative weight of bursa fabricius increased in the groups supplemented 0.2 and $0.3 \%$, relative spleen weight increased with all of dietary WGM and relative abdominal fat was decreased with $0.3 \%$ WGM supplementation. Similar to the present result, Kim et al. (23) indicated that 5\% Korea Panax ginseng leaves did not affect carcass yield. In the study of Ao et al. (3), dietary supplementation of 1,2 and $4 \mathrm{~g} / \mathrm{kg}$ ginseng plant extract did not affect the weights of liver, heart, gizzard and abdominal fat but increased the weights of spleen and bursa Fabricius. Sohn et al. (37) reported that 0.5 and $1 \%$ Sibirya ginseng increased bursa Fabricus weight but did not affect the liver and spleen weight.

In the present study, ginseng root powder addition had no significant effect on blood serum biochemical parameters on day 28 and 38 (Table 4). A quadratic relationship of dietary ginseng root powder level was seen $(\mathrm{P}<0.05)$ with total cholesterol level on day 28. Similarly, some researchers $(3,14,44)$ reported that ginseng root powder did not affect serum triglyceride and cholesterol levels. However some researchers $(32,35)$ reported that dietary ginseng supplementation impaired avian hepatic cholesterogenesis and therefore reduced serum total cholesterol and LDL cholesterol levels in avian species. Qureshi et al. (35) also indicated that ginseng supplementation reduced the $\beta$-hydroxy- $\beta$ methylglutaryl-CoA (HMG-CoA) reductase activity and cholesterol $7 \alpha$-hydroxyylase activity when compared with a diet without ginseng and reported that ginsenoside (saponins) are the bioactive agents for the suppression of cholesterogenesis and lipogenesis. Some researchers (18, 26, 34, 43) also found that serum triglyceride and cholesterol levels decreased with ginseng plant. Kang and Joo (20) concluded that ginseng saponin will partly recover the inhibited LDL biosynthesis in rabbits fed high cholesterol diet. The solubilizing effect of the saponin might stimulate the removal of lipids from the blood (19).

In a study with Japanese quails (33), Panax ginseng powder extract supplementation increased total protein, ALT, AST levels and did not affect urea, creatinine in serum of broilers. Ginseng plant supplementation increased AST, ALT and GGT levels in rats (22), did not affect AST and ALT levels in laying hens (21). Sohn et al. (37) reported that supplementation of 0.5 and $1 \%$ Sibirya ginseng leaf did not affect AST, ALT, albumin, total protein and increased triglyceride, cholesterol and glucose in blood serum. Similarly to the present study, Song et al. (38) concluded that supplementation of ginsan, polysaccharide isolated from the root of Panax ginseng C.A. Meyer, did not affect serum AST and ALT activities and albumin levels.

In the present study, ginseng plant supplementation did not affect erythrocytes (red blood cells, RBC), hematocrit, lymphocyte and platelet distribution width (PDW) and increased haemoglobin, leukocytes (white blood cells, WBC), red blood distribution width (RDW) and mean corpuscular haemoglobin concentration (MCHC) $(\mathrm{P}<0.001)$. A linear relationship of dietary red ginseng root powder level was seen with WBC, haemoglobin, MCHC and RDW (Table 5). These results show that Panax ginseng supplementation strengthen immune cellular defences of the organism (41). Şimşek et al. (41) reported that haemoglobin concentrations, RBC counts, WBC counts and lymphocyte numbers significantly increased with Panax ginseng supplementation to drinking water for 30 days in rats. Ao et al. (3) and Yan et al. (43) indicated that ginseng supplementation did not affect RBC and WBC counts and increased lymphocyte levels $(\mathrm{P}<0.05)$. In the study with laying hens (26), WBC, hematocrit and haemoglobin levels were not affected and $\mathrm{RBC}$ count was increased with ginseng supplementation $(\mathrm{P}<0.05)$.

In the present study, there were no differences among groups in hemagglutination inhibition levels (Table 6). This result is consistent with the findings of Catalan (6). Zhai et al. (45) reported that significantly increased serum heamagglutination inhibition titers against Newcastle disease virus when chickens were intranasally immunized with live Newcastle disease vaccine after drinking water supplemented ginseng stem-leaf saponins at the dose of 2.5 to $10 \mathrm{mg} / \mathrm{kg}$ for $3 \mathrm{~d}$. Zhai et al. (46) indicated significantly increased serum hemagglutination inhibition titers against Newcastle disease virus and avian influenza virus when chickens were intramuscularly injected with inactivated Newcastle disease or avian influenza vaccines following drinking water supplemented $5 \mathrm{mg} / \mathrm{kg}$ ginseng stem-leaf saponins for $7 \mathrm{~d}$. Zhai et al. (47) demonstrated that ginseng stem-leaf saponins provided a better protection against virulent infectious bursal disease virus (IBDV) challenge following vaccination than the control. Zhai et al. (47) concluded that oral administration of ginseng stem-leaf saponins enhances both humoral and gut mucosal immune responses to IBDV and offers a better protection against virulent IBDV challenge. According to Zhai et al. (47), the usage of ginseng saponins might be a potential oral adjuvant for vaccination against infectious diseases in the poultry industry. Kang et al. (21) indicated that red ginseng by-products can be utilized as an immunostimulant for laying hens. Different results can be due to the different adjuvant effects of saponins produced from ginseng plants.

In the current study dietary ginseng root powder supplementation increased the count of Lactobacillus spp. $(\mathrm{P}<0.05)$ and did not affect total aerobic bacteria and coliform number in caecum of broilers on day 38 (Table 7). Quadratic and cubic relationships of ginseng root 
powder level were seen with the count of Lactobacillus spp. $(\mathrm{P}<0.05)$. Hassan et al. (14) observed that dietary fermented ginseng byproducts reduced $E$. coli and Salmonella in ileum but did not affect yeast and Lactobacillus spp. in ileum of broilers. Kang et al. (21) reported that the concentration of Lactobacillus was greater in the red ginseng byproduct groups than that of control group. The concentrations of Salmonella and E.coli in the caecum were not affected by inclusion of red ginseng byproducts in laying hens (21). From the results of present study and some literatures, ginseng plant may contribute to increase the number of Lactobacillus within intestinal microflora. Lactobacillus spp. uses carbohydrates such as inulin and oligofructose and evaluates fructoligosaccharides from these carbohydrates better than other group bacteria in terms of fermentation. Lactobacillus spp. is an indicator microorganisms for flora that mediates good digestive tract functions in poultry, these microorganisms produce short-chain fatty acids that form an acidic environment that suppresses the development of bacteria that emit stinking. In addition, Lactobacillus species are thought to inhibit $E$. coli toxic amin synthesis by secreting antienterotoxins against $E$. coli. Several ginseng constituents have been deemed responsible for the antimicrobial property of ginseng (42).

Different results can be due to the diet composition, ginseng sources, ginseng species, dosage of ginseng and biological active materials of ginseng.

As a conclusion, improvements in relative weight percentages of spleen and some hematological parameters with the addition of $225 \mathrm{mg} / \mathrm{kg}$ and in Lactobacillus spp. count in caecum with the addition of $75 \mathrm{mg} / \mathrm{kg}$ red ginseng root powder were provided in broilers. Further studies are required to determine the effects of its various doses on performance, immunity, antioxidant potential and intestinal microflora under various stress conditions in poultry.

\section{Acknowledgement}

This manuscript is inspired by $\mathrm{PhD}$ thesis of Yavuz Yener. The authors wish to acknowledge Beypi A.Ş. for chicks.

\section{Finacial support}

This study was supported by Ankara University Research Fund (Project No: 16L0239004).

\section{Ethical Statement}

This study was approved by the Ankara University Animal Research Ethics Committee (2015-4-71).

\section{Conflict of Interest}

The authors declared that there is no conflict of interest.

\section{References}

1. ADAS (1981): The Analysis of Agricultural Materials. Ministry of Agriculture, Fisheries and Food, Agricultural Development and Advisory Service, 2nd ed. Her Majesty's Stationery Office, London, UK.

2. Allan WH, Gough RE (1974): A standard haemagglutination inhibition test for Newcastle Disease. 1. A comparison of macro and micro methods. Vet Rec, 95, 120-123.

3. Ao X, Zhou TX, Kim HJ, et al (2011): Influence of fermented Red Ginseng extract on broilers and laying hens. Asian-Australas J Anim Sci, 24, 993-1000.

4. AOAC (2000): Official Methods of Analysis of the Association of Official Analytical Chemists. 17th Ed., AOAC International, Maryland, USA.

5. Carpenter KJ, Clegg KM (1956): The metabolizable energy of poultry feeding stuffs in relation to their chemical composition. J Sci Food Agric, 7, 45-51.

6. Catalan AAS (2011): Panax Ginseng in Diets of Commercial Laying Hens. 67F. Thesis (Master Degree) Animal Sciences Graduate Program. Federal University of Pelotas Pelotas City Rio Grande do Sul State, Brazil.

7. Choi SY, Hong HD, Bae HM, et al (2011): Phytochemical characteristics of coffee bean treated by coating of ginseng extract. J Ginseng Res, 35, 436-441.

8. Chung T, Choi I (2016): Growth performance and fatty acid profiles of broilers given diets supplemented with fermented Red Ginseng marc powder combined with Red Koji. Braz J Poultry Sci, 18, 733-738.

9. Dawson B, Trapp RG (2001): Basic and Clinical Biostatistics, 3rd ed. Lange Medical Books/McGraw-Hill Medical Publishing Division, New York, USA.

10. Eo JK, Choi MS, Eom AH (2014): Diversity of endophytic fungi isolated from Korean ginseng leaves. Mycobiology, 42, 147-151.

11. Farese G, Schmidt JL, Mager M (1967): An automated method for the determination of serum calcium with glyoxal bis (2-hydroxyanil). Clin Chem, 13, 515-520.

12. FDA (2001): Bacteriological Analytical Manual, Chapter 3. Aerobic Plate Count, Avaliable at http://www.fda.gov/Food/ScienceResearch/LaboratoryMet hods/BacteriologicalAnalyticalManualBAM/ucm063346.h tm, 2001. (Accessed March 01, 2019).

13. Glick B (1977): The bursa of fabricius and immunoglobulin synthesis. Int Rev Cytol, 48, 345-402.

14. Hassan R, Choe SH, Ryu SK (2012): A comparison of feeding multi-probiotics and fermented ginseng byproducts on performance, intestinal microflora and immunity of broiler chicks. Korean J Poult Sci, 39, 253-260.

15. Heckert RA, Estevez I, Russek-Cohen E, et al (2002): Effects of density and perch availability on the immune status of broilers. Poult Sci, 81, 451-457.

16. ISO (1998): Microbiology of Food and Animal Feedingstuffs-Horizontal Method for the Enumeration of Mesophilic Lactic Acid Bacteria - Colony-Count Technique at 30 degrees C. ISO 15214:1998. International Organization for Standardization, Geneva, Switzerland.

17. ISO (2006): Microbiology of Food and Animal Feedingstuffs - Horizontal Method for the Enumeration of Coliforms - Colony-Count Technique. ISO 4832:2006. 
International Organization for Standardization, Geneva, Switzerland.

18. Jang HD, Kim HJ, Cho JH, et al (2007): Effect of dietary supplementation of fermented wild ginseng culture by products on egg productivity, egg quality, blood characteristics and ginsenoside concentration of yolk in laying hens. Korean J Poult Sci, 34, 271-278.

19. Kang BH, Joo CN (1985): Biochemical studies on ginseng saponin (XXII). The effect of ginseng saponin on blood serum lipoproteins. Korean Biochem J, 18, 272-278.

20. Kang BH, Joo CN (1986): Biochemical studies on ginseng saponin $(X X V I)$. The effect of ginseng saponin fraction on LDL-receptor of rat and rabbit livers. Korean Biochem J, 19, 168-172.

21. Kang HK, Park SB, Kim CH (2016): Effect of dietary supplementation of red ginseng by-product on laying performance, blood biochemistry, serum immunoglobulin and microbial population in laying hens. Asian Australas J Anim Sci, 29, 1464-1469.

22. Karakuş E, Karadeniz A, Şimşek N, et al (2011): Protective effect of Panax ginseng against serum biochemical changes and apoptosis in liver of rats treated with carbon tetrachloride (CCl4). J Hazard Mater, 195, 208-213.

23. Kim BK, Hwing IU, Kang SS, et al (2002): Effects of dietary Panax ginseng, Dioscorea Japonica and oriental medicine refuse on productivity of Korean native chicken. $\mathrm{J}$ Anim Sci Technol, 44, 297-304.

24. Kim DC, In MJ (2010): Production of hydrolyzed red ginseng residue and its application to lactic acid bacteria cultivation. J Ginseng Res, 34, 321-326.

25. Kim KH, Lee YS, Jung IS, et al (1998): Acidic polysaccharide from Panax ginseng, ginsan, induces Th1 cell and macrophage cytokines and generates LAK cells in synergy with rIL-2. Planta Med, 64, 110-115.

26. Kim YJ, Lee GD, Choi IH (2015): Effects of dietary red ginseng marc on egg production, egg quality and blood characteristics of laying hens. J Appl Anim Res, 43, 242246.

27. Ko SK, Lee CR, Choi YE, et al (2003): Analysis of ginsenosides of white and red ginseng concentrates. Korean J Food Sci Technol, 35, 536-539.

28. Kryeziu AJ, Mestani N, Berisha S, et al (2018): The European performance indicators of broiler chickens as influenced by stocking density and sex. Agron Res, 16, 483491.

29. Lee D, Jeong J, Yu SG, et al (2012): Market segmentation based on attributes for the purchase of fresh ginseng. AIM, 4, 1-10.

30. Lee YS, Chung IS, Lee IR, et al (1997): Activation of multiple effector pathways of immune system by the antineoplastic immunostimulator acidic polysaccharide ginsan isolated from Panax ginseng. Anticancer Res, 17, 323-331.

31. Lim S, Yoon JW, Choi SH, et al (2009): Effect of ginsam, a vinegar extract from Panax ginseng, on body weight and glucose homeostasis in an obese insulin-resistant rat model. Metabolism, 58, 8-15.

32. Muwalla MM, Abuirmeileh NM (1990): Suppression of avian hepatic cholesterogenesis by dietary ginseng. J Nutr Biochem, 1, 518-521.
33. Osfor MMH (1995): Some biochemical and nutritional studies on the effect of Panax ginseng powder on adult Japanese quails. Pol J Food Nutr Sci, 4/45, 73-79.

34. Özcan MA (2016): Japon bildircinlarının rasyonlarına Panax Ginseng kök ekstrakt ilavesinin yumurta verimi ve bazı kan parametreleri üzerine etkileri. Ordu Üniv Bil Tek Derg, 6, 68-74.

35. Qureshi AA, Abuirmeileh N, Din ZZ, et al (1983): Suppression of cholesterogenesis and reduction of $L D L$ cholesterol by dietary ginseng and its fractions in chicken liver. Atherosclerosis, 48, 81-94.

36. Shin JY, Song JY, Yun YS, et al (2002): Immunostimulating effects of acidic polysaccharides exctract of Panax ginseng on macrophage function. Immunopharmacol Immunotoxicol, 24, 469-482.

37. Sohn SH, Jang IS, Moon YS, et al (2008): Effect of dietary siberian ginseng and eucommia on broiler performance, serum biochemical profiles and telomere length. Korean $\mathbf{J}$ Poult Sci, 35, 283-290.

38. Song JY, Akhalaia M, Platonov A, et al (2004): Effects ofpolysaccharide ginsan from Panax ginseng on liver function. Arch Pharm Res, 27, 531-538.

39. Song JY, Han SK, Bae KG, et al (2003): Radioprotective effects of ginsan, an immunomodulator. Radiat Res, 159, 768-774.

40. Song JY, Han SK, Son EH, et al (2002): Induction of secretory and tumoricidal activities in peritoneal macrophages by ginsan. Int Immunopharmacol, 2, 857-865.

41. Şimşek N, Karadeniz A, Karaca T (2007): Effects of the Spirulina platensis and Panax ginseng oral supplementation on peripheral blood cells in rats. Revue Med Vet, 158, 483-488.

42. Tan BKH, Vanitha J (2004): Immunomodulatory and antimicrobial effects of some traditional chinese medicinal herbs: A review. Curr Med Chem, 11, 1423-1430.

43. Yan L, Meng QW, Lee JH, et al (2010): Effects of dietary wild-ginseng adventitious root meal on growth performance, blood profiles, relative organ weight and meat quality in broiler chickens. Asian-Aust J Anim Sci, 24, 258-263.

44. Yıldırım A, Şekeroğlu A, Eleroğlu H, et al (2013): Effects of Korean ginseng Panax Ginseng CA Meyer root extract on egg production performance and egg quality of laying hens. S Afr J Anim Sci, 43, 194-207.

45. Zhai L, Wang Y, Yu J, et al (2011a): Effect of oral administration of ginseng stem-and-leaf saponins (GSLS) on the immune responses to Newcastle disease vaccine in chickens. Vaccine, 29, 5007-5014.

46. Zhai L, Wang Y, Yu J, et al (2011b): Enhancement of humoral immune responses to inactivated Newcastle disease and avian influenza vaccines by oral administration of ginseng stem-and-leaf saponins in chickens. Poult Sci, 90, 1955-1959.

47. Zhai L, Wang Y, Yu J, et al (2014): Enhanced immune responses of chickens to oral vaccination against infectious bursal disease by ginseng stem-leaf saponins. Poult Sci, 93, 2473-2481. 